\title{
Pemanfaatan Selulosa dari Limbah Jerami Padi (Oryza sativa) sebagai Bahan Bioplastik
}

\author{
Rimadani Pratiwi, Driyanti Rahayu, Melisa I. Barliana \\ Fakultas Farmasi Universitas Padjadjaran, Sumedang, Jawa Barat, Indonesia
}

\begin{abstract}
Abstrak
Jerami padi (Oryza sativa) memiliki kandungan selulosa yang cukup tinggi. Selulosa merupakan biopolimer alami yang dapat digunakan sebagai bahan bioplastik. Penelitian ini bertujuan untuk mengetahui apakah selulosa dari limbah jerami padi dapat dimanfaatkan sebagai bahan bioplastik dan bagaimana karakterisasi bioplastik yang dihasilkan dari limbah jerami padi tersebut. Penelitian ini dilakukan dalam beberapa tahapan, yaitu preparasi bahan, pembuatan pulp, pembuatan bioplastik dengan metode inversi fasa dengan variasi jumlah kitosan dan pulp selulosa 3:10, 4:10, dan 5:10, serta karakterisasi bioplastik. Bioplastik yang dihasilkan dari berbagai perbandingan pulp selulosa dan kitosan memiliki karakterisitik yang berbeda-beda. Analisis morfologi menunjukkan bahwa bioplastik yang terbentuk belum homogen dan pada analisis gugus fungsi, tidak ditemukan adanya gugus fungsi baru dalam bioplastik dibandingkan terhadap gugus fungsi yang ada pada bahan pembentuknya. Nilai penyerapan air pada bioplastik dengan perbandingan kitosan dengan pulp selulosa 3:10, 4:10 dan 5:10 adalah $154,65 \%, 119,21 \%$, dan $93,873 \%$. Hasil pengujian sifat mekanik yaitu kuat tarik secara berturutturut adalah 4,2 MPa; 13,8 MPa; dan 4,1 MPa. Dari hasil penelitian dapat disimpulkan bahwa selulosa dari limbah jerami padi dapat dimanfaatkan sebagai bahan bioplastik.
\end{abstract}

Kata Kunci: Bioplastik, jerami padi, selulosa

\section{Utilization of Rice Straw Cellulose (Oryza sativa) as Bioplastics}

\begin{abstract}
Rice straw (Oryza sativa) has a high cellulose contain. Cellulose is a natural biopolymer that can be used as bioplastics. The aim of this research is to determine whether cellulose from rice straw can be used as bioplastics and to characterize the product. Stages of this research are a preparation of materials, pulp manufacture, production of bioplastics using phase inversion method with a variation of chitosan and cellulose pulp ratio are 3:10, 4:10, and 5:10 and characterization of bioplastics. Bioplastics produced from a variety of pulp and chitosan ratio have different characteristics. Morphological analysis on bioplastics surface shows that bioplastics produced in this research is not homogeneous yet and the analysis of functional groups show that there were no new functional groups on bioplastics in comparison to the existing ones in the constituent materials. Water absorption value of bioplastics with chitosan and cellulose pulp ratio $3: 10,4: 10$ and 5:10 were $154.65 \%, 119.21 \%$, and $93.873 \%$. The value of the mechanical properties there is tensile strength of these bioplastics were $4.2 \mathrm{MPa}, 13.8 \mathrm{MPa}$ and 4.1 $\mathrm{MPa}$. According to the result can be concluded that cellulose from rice straw can be used as a bioplastic material.
\end{abstract}

Keywords: Bioplastics, cellulose, rice straw 


\section{Pendahuluan}

Indonesia sebagai negara agraris masih menjadikan pertanian sebagai komoditas utama dalam usaha dan profesi. Jerami padi merupakan bahan lignoselulosa yang tersedia dalam jumlah besar dan belum dimanfaatkan secara optimal di Indonesia. Produksi bioetanol dari jerami padi (Oryza sativa) melalui hidrolisis asam dan fermentasi dengan Saccharomyces cerevisiae. $^{1}$

Selama ini, pemanfaatan limbah jerami belum optimal. Biasanya jerami digunakan untuk pakan ternak dan sisanya dibiarkan membusuk atau dibakar. Hal ini akan menghasilkan polutan $\left(\mathrm{CO}_{2}, \mathrm{NO}_{x}\right.$, $\mathrm{SO}_{x}$ ) yang dapat merusak lingkungan dan penyumbang gas rumah kaca. ${ }^{2}$

Jerami padi adalah bagian batang dan tangkai tanaman padi setelah dipanen butirbutir buahnya. ${ }^{3}$ Jerami padi mengandung $37,71 \%$ selulosa; $21,99 \%$ hemiselulosa; dan 16,62\% lignin. ${ }^{4}$ Kandungan selulosa yang cukup tinggi ini dapat dimanfaatkan dalam berbagai hal antara lain sebagai bahan bioplastik.

Selulosa merupakan biopolymer yang dapat diperoleh dari hasil pertanian. Polimer hasil pertanian mempunyai sifat termoplastik sehingga mempunyai potensi untuk dibentuk atau dicetak menjadi film kemasan. Keunggulan polimer jenis ini adalah tersedia sepanjang tahun (renewable) dan mudah hancur secara alami (biodegradable). ${ }^{5}$ Berdasarkan hal tersebut, polimer jenis ini dapat digunakan sebagai bahan bioplastik yaitu plastik yang dapat diuraikan kembali oleh mikroorganisme secara alami menjadi senyawa yang ramah lingkungan. ${ }^{6}$ Oleh karena itu, selulosa memiliki potensi sebagai bahan bioplastik.

Plastik yang beredar di pasaran saat ini, seperti polivinilklorida (PVC) merupakan polimer sintetik yang terbuat dari minyak bumi yang ketersediaannya semakin menipis dan tidak dapat diperbaharui. Selain itu, plastik jenis ini sulit untuk terurai di alam dan dapat berdampak pada pencemaran lingkungan seperti penurunan kualitas air dan tanah. Plastik berbahan polimer sintetik juga dapat berbahaya bagi kesehatan karena monomer-monomer penyusun polimer sintetik tersebut seperti monomer vinil klorida sebagai unit penyusun PVC bersifat karsinogenik. Monomer-monomer tersebut sulit terurai dalam tubuh sehingga jika terakumulasi dapat menimbulkan gangguan kesehatan dan dapat menyebabkan kanker. ${ }^{7}$

Teknologi bioplastik adalah salah satu upaya yang dilakukan untuk keluar dari permasalahan penggunaan kemasan plastik konvensional. ${ }^{8}$ Selain untuk kemasan, bioplastik juga dapat dimanfaatkan dalam bidang medis dan farmasi antara lain untuk peralatan bedah, benang bedah, kain penyeka, pembalut luka, pengganti tulang dan pelat, dan lain sebagainya. ${ }^{9}$ Pembuatan bioplastik ini dapat dilakukan melalui proses fermentasi dengan bakteri atau dengan metode yang lebih sederhana yaitu mencampurkan polimer alami seperti selulosa dengan bahan tambahan antara lain plastisizer. ${ }^{6,10}$

Polimer plastik biodegradabel yang telah diproduksi saat ini adalah kebanyakan dari polimer jenis poliester alifatik seperti Poli ( $\varepsilon$-kaprolakton) (PCL), Poli (ß-hidroksi butirat) (PHB), Poli (butilena suksinat) (PBS), dan Poli asam laktat (PLA). Beberapa polimer ini memiliki sifat fisik dan mekanik yang kurang baik sehingga penggunannya terbatas. ${ }^{11}$

Berdasarkan uraian tersebut, penelitian ini bertujuan untuk memanfaatkan selulosa dari jerami padi (Oryza sativa), yang selama ini hanya dianggap sebagai limbah pertanian, sebagai alternatif bahan pembentuk bioplastik yang dapat diaplikasikan secara luas.

\section{Metode}

Alat

Alat yang digunakan pada penelitian ini adalah ayakan mesh no. 50, oven (Memmert), scanning electron microscope (JEOL-JSM T330A), spektrofotometer 
inframerah (Shimadzu, IR Prestige-21), timbangan analisis digital (Mettler Toledo), UTM (Universal Testing Machine) (Orientec Co. Ltd, Model UCT-5T), stirrer, pemanas air yang dilengkapi stirer (CIMAREC), pelat kaca dan alat-alat gelas yang biasa digunakan di laboratorium kimia analitik.

Bahan

Bahan tumbuhan:

Jerami padi diperoleh dari daerah Bandung, Jawa Barat.

Bahan kimia:

Bahan yang digunakan dalam penelitian ini adalah natrium hidroksida (Merck), asam sulfat (Merck), aquadestilata (Teknis), asam klorida (Merck), khitosan (PT. Biotech Surindo), gliserol (Teknis), asam asetat (Merck), $\mathrm{NaOCl}$ 12\% (Teknis).

Prosedur

Penelitian dilakukan menggunakan metode eksperimental di laboratorium dengan beberapa tahapan sebagai berikut:

Pengumpulan dan determinasi bahan meliputi pengumpulan bahan dan determinasi tumbuhan yang dilakukan di Herbarium Laboratorium Taksonomi Tumbuhan, Jurusan Biologi, FMIPA, Universitas Padjadjaran, Jatinangor.

Preparasi bahan meliputi pencucian, pengeringan di bawah sinar matahari langsung, perajangan, penggilingan dan pengayakan menggunakan ayakan mesh 50. Kemudian bahan diuji kandungan selulosa dan ligninnya menggunakan metode chesson. $1 \mathrm{~g}$ sampel kering (a) ditambahkan $150 \mathrm{~mL} \mathrm{H} \mathrm{H}_{2} \mathrm{O}$ kemudian direfluks pada suhu $100^{\circ} \mathrm{C}$ dalam water bath selama $1 \mathrm{jam}$. Hasil refluks tersebut kemudian disaring dan residunya dicuci dengan air panas kurang lebih $300 \mathrm{~mL}$. Residu yang diperoleh dikeringkan dengan oven hingga beratnya konstan kemudian ditimbang (b). Residu ditambahkan $150 \mathrm{~mL} \mathrm{H}_{2} \mathrm{SO}_{4} 1 \mathrm{~N}$ kemudian direfluk dalam penangas air selama 1 jam pada suhu $100^{\circ} \mathrm{C}$. Hasilnya disaring sampai netral menggunakan aquades kurang lebih $300 \mathrm{~mL}$ dan dikeringkan (c). Residu kering direndam dalam $10 \mathrm{~mL} \mathrm{H}_{2} \mathrm{SO}_{4} 72 \%$ pada suhu kamar selama 4 jam kemudian ditambahkan $150 \mathrm{mLH}_{2} \mathrm{SO}_{4} 1 \mathrm{~N}$ dan direfluk dalam water bath selama 1 jam. Residu yang diperoleh disaring dan dicuci dengan $\mathrm{H}_{2} \mathrm{O}$ sampai netral kemudian dikeringkan dalam oven dengan suhu $105^{\circ} \mathrm{C}$ dan hasilnya ditimbang (d), selanjutnya residu diabukan dan ditimbang (e). Perhitungan kadar selulosa dan kadar lignin adalah sebagai berikut:

Kadar seluosa $=(\mathrm{c}-\mathrm{d}) / \mathrm{a} \times 100 \%$

Kadar lignin $=(\mathrm{d}-\mathrm{e}) / \mathrm{a} \times 100 \%$

Pembuatan pulp dari jerami padi menggunakan metode yang mengacu pada metode yang digunakan oleh M.Z. Norashikin dan M.Z. Ibrahim ${ }^{12}$ dengan modifikasi. Pembuatan pulp dilakukan dengan merendam tiap $10 \mathrm{~g}$ jerami dengan $200 \mathrm{ml} \mathrm{NaOH} \mathrm{4 \%} \mathrm{sambil} \mathrm{dipanaskan} \mathrm{selama}$ 1 jam, kemudian disaring, dinetralkan dan dikeringkan. Setiap $2 \mathrm{~g}$ dari hasil tersebut, ditambahkan $36 \mathrm{ml} \mathrm{HCl} 0,2 \mathrm{M}$ sambil dipanaskan selama 2 jam, kemudian disaring dan dinetralkan, lalu ditambahkan $\mathrm{NaOCl} 12 \% \mathrm{~b} / \mathrm{v}$, setelah itu dikeringkan dalam oven. Hasil yang diperoleh dibilas dengan aquades hingga bebas klorin dan dikeringkan kembali. Sebanyak 2 g dari hasil yang diperoleh ditambahkan $100 \mathrm{ml}$ aquades, dipanaskan hingga terbentuk pulp.

Pembuatan bioplastik dilakukan dengan metode inversi fasa. Orientasi dilakukan terlebih dahulu terhadap jumlah pulp yang dicampurkan dengan $3 \mathrm{ml}$ gliserol. Variasi pulp yang digunakan adalah $0,5 \mathrm{~g} ; 1 \mathrm{~g} ; 1,5$ $\mathrm{g} ; 2$ g. Hasil orientasi terbaik dicampurkan dengan kitosan yang dilarutkan dalam asam asetat 1\% dengan perbandingan kitosan dan pulp 3:10;4:10; dan 5:10. Larutan dicetak di atas plat kaca dan dikeringkan pada oven $50^{\circ} \mathrm{C}$. Setelah kering untuk pelepasan bioplastik dari plat tersebut, direndam dalam $\mathrm{NaOH} 2 \%$ kemudian dikeringkan dengan udara bebas.

Karakterisasi bioplastik meliputi 
analisis gugus fungsi menggunakan alat FTIR, analisa morfologi menggunakan alat SEM (Scanning Electron Microscopy), uji ketahanan air, dan pengujian sifat mekanik menggunakan alat UTM (Universal Testing Machine) yang di uji sesuai ISO 527 Tipe $5 \mathrm{~A}$.

\section{Hasil}

Hasil pengumpulan dan determinasi bahan

Jerami padi diperoleh dari daerah Bandung, Jawa Barat. Determinasi tumbuhan jerami padi dilakukan di Herbarium Jatinangor, Laboratorium Taksonomi Tumbuhan, Jurusan Biologi FMIPA Unpad dengan nomor surat hasil determinasi adalah 54/HB/01/2012.

Hasil preparasi bahan

Hasil preparasi bahan, jerami menjadi serbuk halus berwarna kuning coklat. Setelah itu di uji kandungan selulosa dan ligninnya, hasil pengujian dapat dilihat pada Tabel 1.

Hasil pembuatan pulp

Pada proses pembuatan pulp ini, pulp berubah warna dari coklat menjadi putih kuning.

Hasil pembuatan bioplastik

Dari hasil orientasi, jumlah pulp $2 \mathrm{~g}$ memberikan hasil terbaik, ditinjau dari elastisitasnya yang diamati secara manual yaitu dilihat saat pelepasan dari plat tidak

Tabel 1 Hasil pengujian kadar selulosa dan kadar lignin

\begin{tabular}{cll}
\hline Pengujian & $\begin{array}{c}\text { Kadar } \\
\text { selulosa }\end{array}$ & $\begin{array}{c}\text { Kadar } \\
\text { lignin }\end{array}$ \\
\hline 1 & $20,52 \%$ & $3,60 \%$ \\
2 & $21,29 \%$ & $1,57 \%$ \\
3 & $24,42 \%$ & $5,28 \%$ \\
Rata-rata & $22,07 \%$ & $3,48 \%$ \\
Stdev & 2,06 & 1,86 \\
\hline
\end{tabular}

mudah patah dibanding yang lain, selain itu juga masih dapat ditekuk.

Setelah orientasi jumlah pulp tersebut, selanjutnya pembuatan bioplastik dilakukan dengan mencampurkan kitosan dan gliserol ke dalam pulp. Variasi perbandingan jumlah kitosan dengan pulp yang digunakan adalah $3: 10 ; 4: 10$; dan 5:10.

Bioplastik yang dihasilkan dapat dilihat pada Gambar 1.

Hasil karakterisasi bioplastik

Bioplastik yang diperoleh di karakterisasi untuk mengetahui sifatsifatnya. Karakterisasi yang dilakukan meliputi :

Analisis gugus fungsi

Hasil analisa gugus fungsi menggunakan FTIR dapat dilihat pada Tabel 2.

Analisis Morfologi

Analisis morfologi dilakukan dengan menggunakan SEM untuk mengetahui morfologi permukaan bioplastik yang terlihat seperti pada Gambar 2.

Uji Ketahanan Air

Hasil pengujian ketahanan air dapat dilihat pada Gambar 3.

Kuat tarik (tensile strength)

Hasil pengukuran kuat tarik pada bioplastik dapat dilihat pada Gambar 4.

Tabel 2 Hasil Identifikasi spektrum FTIR bioplastik

\begin{tabular}{ccc}
\hline No & $\begin{array}{c}\text { Bilangan gelombang } \\
(\mathbf{c m}-\mathbf{1})\end{array}$ & Identifikasi \\
\hline 1 & 3784,37 & N-H streching \\
2 & 3419,34 & O-H streching \\
3 & 2943,40 & C-H streching \\
4 & 1400,81 & C-O streching \\
5 & 1040,12 & C-N streching \\
\hline
\end{tabular}



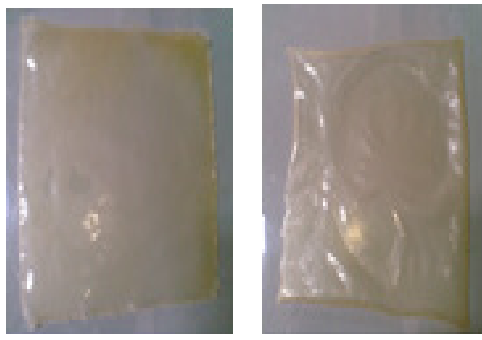

Gambar 1 Hasil bioplastik

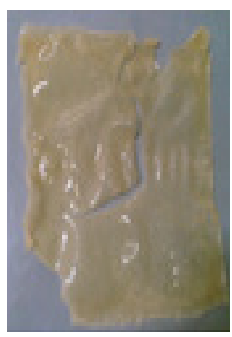

\section{Pembahasan}

Preparasi bahan

Pengecilan ukuran partikel pada preparasi bahan dimaksudkan untuk memperluas permukaan kontak karena semakin kecil ukuran partikel, maka semakin besar luas permukaan padatan per satuan luas volume tertentu, sehingga akan semakin banyak zat yang teradsorpsi. ${ }^{13}$

Hasil pengujian kadar selulosa dan lignin pad Tabel 1. menunjukkan bahwa, rata-rata kadar selulosa jerami yang digunakan adalah sekitar 22,07\% dengan kandungan lignin rata-rata sekitar 3,48\%. Secara umum kandungan selulosa pada jerami adalah $37,71 \% .{ }^{4}$ Perbedaan ini dapat disebabkan karena sumber tanaman jerami yang berbeda, kondisi tanaman, tanah, penanaman dan lain-lain. ${ }^{2}$

Pembuatan pulp

Pada proses pembuatan pulp, jerami direaksikan dengan $\mathrm{NaOH}$ 4\%. Hal ini

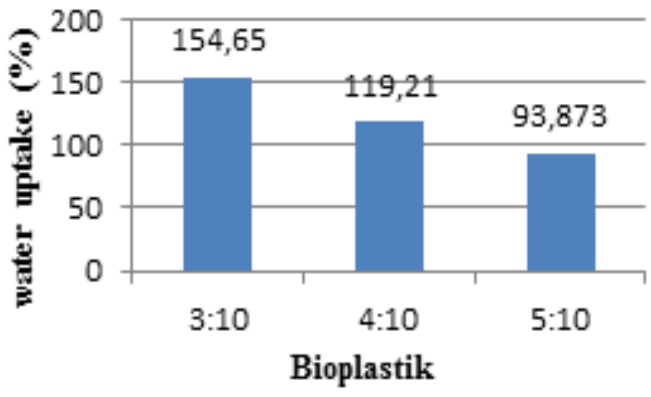

Gambar 3 Hasil pengujian nilai ketahanan air pada bioplastik

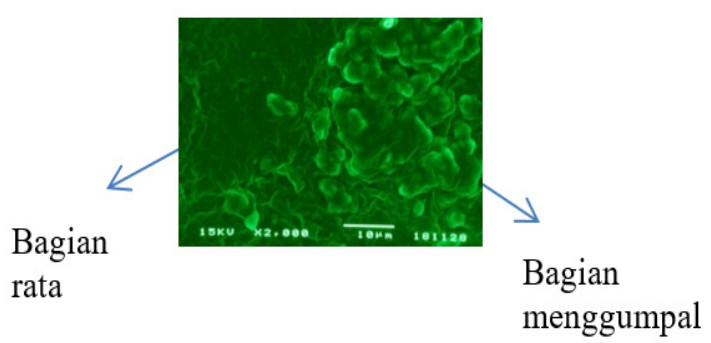

Gambar 2 Penampang atas bioplastik perbandingan kitosaan dan pulp 5:10 dengan perbesaran 2000x

bertujuan untuk meluruhkan lignin (proses delignifikasi). Delignifikasi dilakukan karena lignin dapat meningkatkan kekakuan suatu bahan. ${ }^{14}$ Selanjutnya ditambahkan dengan HCL 0,2M untuk meluruhkan hemiselulosa sehingga hanya selulosa yang terkandung dalam pulp. Hemiselulosa perlu dihilangkan karena dapat meningkatkan kerapuhan bahan. ${ }^{15}$ Setelah itu ditambahkan $\mathrm{NaOCl}$. Penambahan $\mathrm{NaOCl}$ ini sebagai proses pemutihan pulp. Proses pemutihan pulp adalah peristiwa perusakan (degradasi) sisa lignin yang masih tersisa yang terdapat dalam pulp dengan perlakuan bahan kimia untuk merubah warna dan memberikan kecerahan yang lebih tinggi pada pulp.

Pembuatan bioplastik

Pembuatan bioplastik dilakukan dengan metode inversi fasa dengan teknik penguapan pelarut (solvent casting). Teknik ini dipilih karena merupakan teknik yang paling sederhana. Pada metode ini polimer dilarutkan dalam suatu pelarut, dan polimer

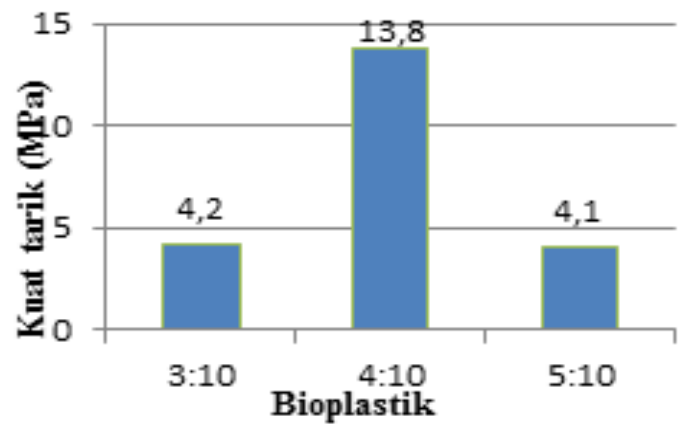

Gambar 4 Grafik hasil pengukuran kuat tarik bioplastik 
yang telah terbentuk dicetak pada suatu pendukung, contohnya seperti plat kaca. Pelarut dibiarkan menguap, sehingga dihasilkan lapisan polimer yang rapat. ${ }^{16}$

Orientasi jumlah pulp dilakukan untuk mengetahui jumlah pulp yang dapat memberikan hasil terbaik. Setelah diperoleh orientasi jumlah pulp tersebut, selanjutnya pembuatan bioplastik dilakukan dengan mencampurkan kitosan dan gliserol ke dalam pulp. Kitosan berfungsi sebagai biopolimer pencampur dan gliserol berfungsi sebagai plastisizer sehingga diharapkan dapat menghasilkan bioplastik yang memiliki sifat fisik dan mekanik yang lebih baik.

\section{Karakterisasi bioplastik}

Analisa gugus fungsi dilakukan untuk mengetahui gugus fungsi apa saja yang terdapat pada bioplastik yang dihasilkan berdasarkan bilangan gelombang dimana suatu peak muncul.

Hasil identifikasi gugus fungsi (Tabel 2) menunjukkan bahwa semua gugus fungsi yang muncul berasal dari bahan yang digunakan yaitu selulosa yang memiliki gugus $\mathrm{OH}, \mathrm{C}-\mathrm{O}$, dan $\mathrm{C}-\mathrm{H}$; kitosan yang memiliki gugus fungsi $\mathrm{O}-\mathrm{H}, \mathrm{N}-\mathrm{H}, \mathrm{C}-\mathrm{O}$, dan $\mathrm{CH}$; dan gliserol yang memiliki gugus fungsi $\mathrm{O}-\mathrm{H}, \mathrm{C}-\mathrm{O}$, dan $\mathrm{C}-\mathrm{H}$.

Berdasarkan hasil identifikasi tersebut, tidak ditemukan adanya gugus fungsi baru yang terbentuk. Hal tersebut menandakan biopolastik yang dihasilkan merupakan produk dari proses blending secara fisika sehingga bioplastik ini memiliki sifat seperti komponen-komponen penyusunnya. ${ }^{17}$

Hasil analisis morfologi pada Gambar 2 menunjukkan bahwa permukaan bioplastik tidak rata. Pada permukaannya ada bagian yang lebih halus dan bagian yang kasar. Hal ini menunjukkan bahwa bahan tidak tercampur secara homogen. Pada bagian permukaan yang halus menunjukkan bahwa bahan-bahan yang digunakan dapat tercampur dengan baik sehingga menghasilkan permukaan yang rata sedangkan pada bagian permukaan yang kasar tampak gumpalan-gumpalan dan rongga yang menunjukkan pencampuran bahan belum sempurna.

Uji ketahanan air dilakukan untuk mengetahui sejauh mana bioplastik ini tahan terhadap air karena pada aplikasinya, plastik sering berinteraksi dengan air.

Pada Gambar 3 terlihat bahwa semakin banyak jumlah kitosan yang digunakan, maka nilai persen air yang diserap semakin kecil. Hal ini menunjukkan bahwa kitosan mempengaruhi sifat dari bioplastik yang dihasilkan. Gabungan selulosa dan kitosan membuat plastik memiliki sifat ketahanan air karena sifat keduanya yang tidak larut air. Disamping itu, semakin tinggi konsentrasi kitosan maka jarak antar molekul dalam bioplastik akan semakin rapat karena rongga antar selulosanya terisi oleh molekul kitosan.

Jika dibandingkan dengan plastik konvensional, nilai ketahanan air dari produk bioplastik yang dihasilkan lebih tinggii. Keuntungan derajat swelling yang tinggi adalah mudahnya degaradasi oleh air. Degradasi ini memang tidak terjadi secara kimia, melainkan secara fisik yaitu dari bentuk plastik yang besar menjadi fragmenfragmen kecil.

Tabel 3 Perbandingan sifat mekanik dan sifat fisik plastik ${ }^{21}$

\begin{tabular}{cccccccccc}
\hline \multirow{2}{*}{ Sifat } & \multicolumn{3}{c}{ Bioplastik penelitian } & \multirow{2}{*}{ PLA } & \multirow{2}{*}{ PCL } & \multirow{2}{*}{ PBSA } & \multirow{2}{*}{ PBAT } & \multirow{2}{*}{ PP } & PET \\
& $\mathbf{3 : 1 0}$ & $\mathbf{4 : 1 0}$ & $\mathbf{5 : 1 0}$ & & & & & & \\
\hline Swelling (\%) & 154,65 & 119,21 & 93,87 & 172 & 177 & 330 & 550 & 0,01 & 0,15 \\
Kuat Tarik (MPa) & 4,2 & 13,8 & 4,1 & - & 14 & 19 & 9 & $24,7-302$ & 45,52 \\
\hline
\end{tabular}

Keterangan: PLA : Poli Lactic Acid; PCL : Poli (ع-kaprolakton); PBSA : Poli Butilena Suksinat Adipate; PBAT : Poly(butylene adipate-co-terphthalate); PP : poli propilen; $\mathrm{PET}=$ Poli etilen Terphtalat 
Salah satu pengujian suatu polimer yang sering diujikan untuk mengetahui kualitasnya, terutama golongan plastik adalah pengujian sifat mekanik. Dalam penelitian ini pengujian sifat mekanik yang dilakukan adalah penentuan nilai kuat tarik.

Nilai kuat tarik menunjukkan kekuatan tarik plastik yang dihasilkan ketika mendapat beban. Nilai tersebut menggambarkan kekuatan tegangan maksimum bahan untuk menahan gaya yang diberikan. ${ }^{18}$

Pada Gambar 4 terlihat bahwa nilai kuat tarik terbesar diperoleh pada bioplastik dengan perbandingan 4:10, setelah itu nilai kuat tariknya turun kembali pada perbandingan 5:10.

Penambahan kitosan menyebabkan terbentuknya interaksi dengan rantai polimer selulosa dalam bentuk ikatan hidrogen, dimana interaksi rantai polimer ini terbentuk untuk meningkatkan kecepatan respon viskoelastis pada polimer sehingga dapat meningkatkan mobilitas molekuler rantai polimer. Meningkatnya mobilitas molekuler rantai polimer ini menyebabkan nilai kuat tarik akan semakin meningkat. Peningkatan tersebut akan berlaku selama masih terbentuk interaksi rantai polimer. ${ }^{19}$

Namun pada bioplastik 5:10, nilai kuat tarik mengalami penurunan. Penurunan tersebut dikarenakan peningkatan konsentrasi kitosan tidak diikuti oleh pembentukan interaksi dengan rantai polimer bioplastik. Pembentukan interaksi melalui adanya ikatan hidrogen antara selulosa, kitosan dan gliserol akan terjadi apabila masih ada gugus $\mathrm{OH}$ yang bebas yang dapat berikatan antara senyawa tersebut..$^{20}$ Apabila tidak terdapat gugus $\mathrm{OH}$ bebas maka senyawa yang ditambahkan akan ada yang tetap berdiri sendiri sebagai molekulnya tanpa adanya ikatan dengan molekul lain. Hal inilah yang menyebabkan nilai kuat tarik pada peningkatan konsentrasi kitosan bioplastik 5:10 mengalami penurunan. Kitosan yang ditambahkan jika berlebih tidak dapat lagi membentuk ikatan hidrogen dengan selulosa ataupun gliserol karena sudah tidak terdapat gugus $\mathrm{OH}$ bebas.

Tabel 3 menunjukkan perbandingan karakteristik antara bioplastik yang dihasilkan dengan beberapa bioplastik dan plastik konvensional yang beredar di pasaran. Dari Tabel 3 dapat terlihat bahwa nilai densitas dan swelling bioplastik yang dihasilkan pada penelitian ini mendekati nilai dari bioplastik-bioplastik lain. Sementara sifat mekanik lain yang berbeda dapat digunakan sebagai acuan untuk memperbaiki sifat plastik yang telah ada. Misalnya pencampuran dengan PP dapat meningkatkan biodegradabilitas dari PP karena nilai swelling bioplastik yang tinggi dapat mempercepat proses biodegradasi.

\section{Simpulan}

Dari hasil penelitian dapat disimpulkan bahwa selulosa dari limbah jerami padi dapat dimanfaatkan sebagai bahan bioplastik. Variasi kombinasi pulp selulosa dan kitosan yang berbeda menghasilkan karakteristik bioplastik yang berbeda pula.

Pada analisis morfologi, secara umum bioplastik yang terbentuk belum homogen dan pada analisis gugus fungsi, tidak ditemukan adanya gugus fungsi baru pada bioplastik dibandingkan terhadap gugus fungsi yang ada pada bahan pembentuknya.

Nilai penyerapan air pada bioplastik dengan perbandingan kitosan dengan pulp selulosa 3:10, 4:10 dan 5:10adalah $154,65 \%, 119,21 \%$ dan 93,873\%. Hasil pengujian sifat mekanik yaitu kuat tarik secara berturut-turut adalah 4,2 $\mathrm{MPa}, 13,8$ $\mathrm{MPa}$, dan 4,1 MPa.

\section{Daftar Pustaka}

1. Hayuningtiyas, S.K., Sunarto, Sari, S.L.A, Bioteknologi 11(1):1-4, Mei 2014, ISSN: 0216-6887, EISSN: 23018658, DOI: 10.13057/biotek/c110101

2. Novia, Windarti, A dan Rosmawati. Pembuatan Bioetanol Dari Jerami Padi Dengan Metode Ozonolisis- 
Simultaneous Saccharification and Fermentation (SSF). Jurnal Teknik Kimia No. 3, Vol. 20, Agustus 2014, hal 39

3. Komar, A. Teknologi Pengolahan Jerami Padi Sebagai Pakan Ternak. Bandung: Dian Grahita. 1984.

4. Dewi. Hidrolisis Limbah Hasil Pertanian Secara Enzimatik. Akta Agrosia. 2002. No. 2, Vol. 5, $67-71$.

5. Shofyan, Mohamad. Jenis Biopolimer. 2010. Tersedia dari: http://forum.upi. edu/v3/index.php?topic $=15650.0$

[Diakses 12 Februari 2012]

6. Sanjaya, I Gede dan T. Puspita. Pengaruh Penambahan Khitosan dan Plasticizer Gliserol pada Karakteristik Plastik Biodegradable dari Pati Limbah Kulit Singkong. Skripsi, Teknik Kimia FTI-ITS. 2011.

7. Siswono. Jaringan Informasi pangan dan Gizi, volume XIV. Jakarta: Ditjen Bina Gizi Masyarakat. 2008.

8. Darni, Yuli., A. Chici, S. Ismiyati. Sintesa Bioplastik dari Pati Pisang dan Gelatin dengan Plasticizer Gliserol. Universitas Lampung, Seminar Nasional Sains dan Teknologi-II. 2008.

9. Kolybaba, M., L.G. Tabil, S. Panigrahi, W.J. Crerar, T.Powell, B. Wang. Biodegradable Polymers : Past, Present, and Future. Paper is presented in ASAE Annual Intersectional Meeting Sponsored by the Red River Section of ASAE, Quality Inn \& Suites, 301 3rd Avenue North Fargo, North Dakota, USA, October 3-4, 2003.

10. Ningsih, Sri Widia. Pembuatan Bioplastik Polihidroksialkanoat Menggunakan Bakteri Mesofilik dan Media Limbah Cair Pabrik Kelapa Saawit. Tesis, FMIPA-USU. 2010.

11. Pranamuda. Pengembangan Bahan Plastik Biodegradabel Berbahan Baku Pati Tropis. Badan Pengkajian dan Penerapan Teknologi Jakarta. Weblog Biology Resources on Shantybio. 2009.

12. Norashikin, M.Z. and M.Z. Ibrahim. Fabrication and Characterization of
Sawdust Composite Biodegradable Film. World Academy of Science, Engineering and Technology 65. 2010.

13. Sulistyawati, S. Modifikasi Tongkol Jagung sebagai Adsorben Logam Berat $\mathrm{Pb}$ (II). [Skripsi]. Bogor : Departemen Kimia, Fakultas Matematika dan Ilmu Pengetahuan Alam Institut Pertanian Bogor. 1-28. 2008.

14. Fox, C. Chemical and Thermal Characterization of Three Industrial Lignins and Their Corresponding Lignin Esters. 2006. [Tesis]. USA: University of Idaho. 3-5. Tersedia di: http//:www. uidaho.edu [Diakses 13 Januari 2012]

15. Ji, Y. 2007. Kinetics and Mechanism of Oxygen Delignification. [Tesis]. Finlandia: University of Maine. 3-55.

16. Porter, M.C. Handbook of industrial membrane technology. Noyes Publication. New Jersey. 1990.

17. Darni, Yuli., H. Utami dan S. N. Asriah. Peningkatan Hidrofobisitas dan Sifat Fisik Plastik Biodegradabel Pati Tapioka dengan Penambahan Selulosa Residu Rumput Laut Euchema Spinossum. Universitas Lampung. Seminar Hasil Penelitian \& Pengabdian Kepada Masyarakat. 2009.

18. Surdia, T. dan S. Saito. Pengetahuan Bahan Teknik. Jakarta: PT Pradya Paramita. 1995.

19. Juari. Pembuatan dan Karakterisasi Bioplastik dari Poly-3-Hidroksialkanoat (PHA) yang Dihasilkan Ralstonia Eutropha pada Hidrolisat Pati Sagu dengan Penambahan Dimetil Ftalat (DMF). Skripsi. Teknik pertanian. IPB. 2006.

20. Lim, S. Synthesis of a Fiberreactive Chitosan Derivative and Its Application to Cotton Fabric as an Antimicrobial Finish and Dyeingimproving Agent. Tesis. Department of Fiber and Polymer Science, North Caroline State University. 2002.

21. Pandey, A., P. Kumar, and V. Singh. Application of Bioplastics in Bulk Packaging: A Revolutionary and 
Sustainable Approach. 2010. Tersedia di: http://www.indiapackagingshow. com [Diakses 12 Februari 2012]. 